W. E. WRATHER, DIREC'TOR

\title{
PHOTOGEOLOGIC MAP OF THE ELK RIDGE-6 QUADRANGLE SAN JUAN COUNTY, UTAH \\ By
}

J. S. Detterman and J. C. Reed, Jr.

MISCELLANEOUS GEOLOGIC INVESTIGATIONS

MAP I-98

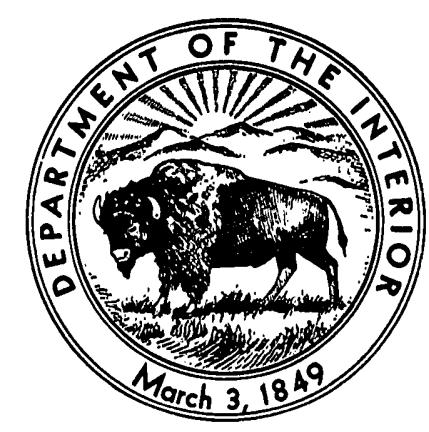

PUBLISHED BY THE U. S. GEOLOGICAL SURVEY WASHINGTON. D. C. 